\title{
Перспективи використання підземних мінеральних вод Східного регіону України у реабілітації пацієнтів з остеоартрозами та дорсопатіями
}

\author{
Польщакова Т. В., Гуща С. Г, Новікова А. І. \\ ДУ «Український науково-дослідний інститут медичної реабілітації та курортології МОЗ України, \\ м. Одеса, Україна
}

Актуальність. Зміни в суглобах при остеоартрозах $(\mathrm{OA})$ та остеохондрозі хребта $(\mathrm{OXX})$ обумовлені прогресуючими дистрофічними, некробіотичними та репаративними процесами, надходженням токсичних продуктів напіврозпаду продуктів метаболізму, що потребує долучення до процесу систем детоксикації, які активують мінеральні води (МB). За умов застосування MB різного катіонно-аніонного складу проявляються особливості клінічного впливу на перебіг захворювань.

Мета дослідження: дослідження терапевтичної ефективності від зовнішнього застосування МВ - бромних залізистих розсолів, хлоридних кальцієво-натрієвих, слабкокислих 3 мінералізацією 40,88 г/дм ${ }^{3}$ свердловини (свр.) № 1359 с. Вербки Дніпропетровської області у пацієнтів із захворюваннями хребта і суглобів.

Матеріали та методи дослідження. Клінічні, клініко-лабораторні, клініко-функціональні, статистичні.

Результати дослідження та їх обговорення. Бальнеотерапію застосовували у 15 хворих (основа група) на гонартроз, коксартроз II-III ст. 3 незначним або помірним обмеженням руху, деформуючі дорсопатії 3 корінцевим синдромом, яким до традиційного курсу санаторно-курортного лікування (фізіотерапія, масаж, ЛФК) додавали курс бальнеотерапії з вказаною $\mathrm{MB}\left(\mathrm{t}^{\circ}\right.$ від 35 до $37^{\circ} \mathrm{C}$, від
12 хв до 15 хв, 2 дні поспіль, 3 днем перерви, на курс 12 ванн); 10 хворих (контрольна група), які отримували тільки традиційний курс.

Під впливом курсового зовнішнього застосування даної МВ інтенсивність больового синдрому за шкалою ВАШ у суглобах та хребті зменшилась від $5,4 \pm 0,2$ балів до $4,6 \pm 0,2$ балів $(\mathrm{p}<0,05)$, лейкоцитозу - від $10,6 \pm 0,310^{9} / 1$ до $8,6 \pm 0,410^{9} / 1(\mathrm{p}<0,05)$, ШОЕ - від 11,2 $\pm 0,4$ мм/год до 9,1 $\pm 0,3$ мм/ год ( $\mathrm{p}<0,05)$, рівень загального білірубіну у крові - від 15,0 мкмоль/л до 13,8 мкмоль/л на фоні збільшення на 19,8\% рівня прямого білірубіну відносно екскреції загального. У контролі зміни не носили такої вираженої тенденції (загальний білірубін від 15,1 $\pm 1,2$ мкмоль/л до $15,1 \pm 0,9$ мкмоль/л, прямий від 3,2 \pm 0,2 мкмоль/л до 3,5 $\pm 0,3$ мкмоль/л).

Висновки. Застосування даної МВ покращує клінічну картину захворювань, рівень неспецифічних адаптаційних реакцій пацієнтів за даними лейкоцитарних формул, який зріс від $640 \pm 127,1$ балів до 967,5 $\pm 241,4$ балів, активує метаболізм, дезінтоксикаційну функцію печінки.

Ключові слова: бальнеотерапія, мінеральні води, гонартроз, коксартроз.

Перспективи подальших досліджень. Дослідження впливу даних мінеральних вод у пацієнтів 3 іншими хронічними захворюваннями. 